\title{
Dissociative effects in different prime domains
}

\author{
DOUGLAS L. NELSON \\ University of South Florida, Tampa, Florida \\ MARY J. LALOMIA \\ IBM Corporation, Boca Raton, Florida \\ and \\ JOSE J. CANAS \\ University of Granada, Granada, Spain
}

\begin{abstract}
These experiments were performed to examine the effects of different types of primes across variations in prime set size, prime strength, and prior study in verification and lexical decision tasks. The primes consisted of taxonomic category names, associates, or rhymes that defined either small or large sets of related concepts, and they were either strongly or weakly related to their targets. Targets either were or were not studied prior to the priming task. The results indicated that, for taxonomic primes, shorter decision latencies were obtained when set size was smaller and when the target was studied before the priming task. In contrast, for rhymes, neither set size nor prior study had reliable effects. For all three types of primes, decision latencies were faster for stronger than for weaker prime-to-target relationships. These findings are contrasted with the results of manipulating these variables in episodic tasks such as cued recall, and they are interpreted in the context of a components-of-processing approach.
\end{abstract}

Variables sometimes have different effects in different tests of memory. For example, manipulations of levels of processing, amnesia, and aging have greater effects on direct tests such as recall and recognition than on indirect tests such as fragment completion and perceptual identification (see, e.g., Graf \& Mandler, 1984; Jacoby \& Dallas, 1981; Light \& Singh, 1987; Squire, Shimamura, \& Graf, 1985). These interaction effects have been called dissociations (Tulving, 1985), and these dissociations in conjunction with other effects have been used to support different theoretical approaches to the explanation of memory phenomena.

In the multiple-memory approach, dissociations are used to support the hypothesis that memory consists of different systems (Cohen \& Squire, 1980; Tulving, 1985) or different forms (Graf $\&$ Schacter, 1987). The assumption underlying this view is that different retention tests tap into different kinds of memory that are differentially sensitive to the effects of the manipulated variables. In contrast, the components-of-processing approach interprets such dissociations as indicating that different component processes are involved to varying degrees in different retention tests (Jacoby, 1983; Nelson, Canas, Bajo, \& Keelean, 1987; Nelson, Keelean, \& Negrao, 1989;

\footnotetext{
This research was supported by Grant NIMH 16360 to Douglas L. Nelson from the National Institute of Mental Heaith. Special thanks are offered to Cathy McEvoy for her helpful comments on this paper. Correspondence concerning this article should be sent to Douglas Nelson, Department of Psychology, University of South Florida, Tampa, FL 33617
}

Roediger \& Blaxton, 1987). The main assumptions underlying this approach are that there are a finite number of processing operations, and that, because of differences in cue information and task characteristics, retention tests differentially rely on various component processes.

The present paper was conceptualized within the component process framework, and it is focused on the manipulation of types of retrieval cues, their set size, and their strength. The cues consisted of taxonomic category names, meaningful associates, or rhymes; these cues defined either small or large sets of naturally related instances; and they were either strongly or weakly related to their targets. The effects of these variables have been explored extensively in the extralist cued recall task (e.g., see Nelson, 1989, for a review). In this task, subjects study a list of words and are then given a cue to prompt or prime the recall of each studied word during test. These cues are extralist cues because they appear only at test and do not appear with the target words during the study trial.

The results of these studies have shown that, for taxonomic, rhyme, and associatively related cues, those that define smaller sets of related instances or that are more strongly related to their targets are more effective than those that define larger sets or that are more weakly related (see, e.g., Nelson \& McEvoy, 1979; Nelson, McEvoy, \& Friedrich, 1982). These effects are important, because they demonstrate that preexisting memories in meaning and in rhyme domains play a role in an episodic memory task. For example, effects of cue set size indicate that recall is not only a function of events occurring during study, but also of the number of memories linked to the 
test cue through learning that occurs prior to the laboratory episode (Nelson, 1989).

Such preexisting memories, however, do not play an equally important role in all episodic tasks. Although setsize effects are found in extralist cued recall, they generally are not found in standard recognition tests when the target itself is presented as the test cue (Nelson, Canas, \& Bajo, 1987). This task difference is attributed to a search component presumed to be present in the extralist cuing test and absent in the recognition test. In the cuing task, the cue provides only partial information about the target, and a search is required. Theoretically, the cue automatically activates a set of related instances in the domain of information specified by the instructions, and a search for the representation of the target in this domain is conducted. With larger sets, the likelihood of recovering this representation is lower, and, given that recall is correct, latency to produce the correct response is longer (Nelson, 1989; Nelson, McEvoy, \& Bajo, 1988). In the recognition test, the target itself serves as the test cue, and a search of its related instances is normally not required in order to produce the correct response (Nelson, Canas, \& Bajo, 1987).

In the present experiments, the purpose was to determine whether set-size and strength effects for various types of primes would be apparent in verification and lexical decision tasks. In these tasks, subjects view a cue or a prime, which is followed shortly thereafter by a target. In the verification task, subjects verify that the target is related to the prime (Chumbley, 1986; Wilkins, 1971), and, in the lexical decision task, they judge the lexical status of the target (see, e.g., Meyer, Schvaneveldt, \& Ruddy, 1974). Priming occurs when the presentation of the prime produces faster responses for related targets than for unrelated targets, and, theoretically, priming is attributed to speeded access to the representation of the target (see Neely, 1990, for a review).

Priming effects have been found for all three types of primes, and such effects were expected in these experiments (see, e.g., Canas, 1990; Chumbley, 1986; Hillinger, 1980). Our interest, however, was not focused on determining whether priming effects would be found, but on determining whether decision times in verification and lexical decision tasks would vary with prime set size, prior study, and prime strength, and whether these effects would parallel those found in episodic tasks such as extralist cued recall. Previous research done with meaningfully related primes has shown mixed results for manipulations of set size (e.g., Chang, 1986) and strength (e.g., Canas, 1990) in priming tasks. These variables have not been investigated for rhyme primes.

These priming tasks differ in many ways from the extralist cuing task, but they share the fact that performance is driven by a prime or cue that is related to the target in some specified domain. Characteristics of the prime should be critical in each task, but parallel effects of the manipulated variables may or may not be obtained. On the one hand, if parallel effects of set size and strength are found for all types of cues in the priming tasks, as in the cued recall task, the findings would be consistent with the hypothesis that the processing components present in the episodic cuing task are also present in priming tasks. Although interesting, such results would not be useful for determining whether the same or different processing components underlie strength and set-size effects in these two types of tasks. Both effects could be produced by processes associated with spreading activation (see, e.g., Anderson, 1983) or by processes associated with search and sampling (Nelson, 1989; Raaijmakers \& Shiffrin, 1981). On the other hand, a consistent pattern of dissociations involving prime domain, set size, and strength would suggest that different component processes may be involved in priming and, by inference, in cuing tasks. Depending on the nature of the dissociations, such differences were expected to be useful for identifying the specific nature of the processes underlying the effects of each variable.

In Experiment 1, primes consisted of either taxonomic category names or rhymes that normatively defined sets of different sizes, ranging from a few to approximately 20 instances. Preexisting prime-to-target strength was controlled for both types of primes, and subjects were asked to decide whether the target was related to its primethat is, to verify relatedness. In Experiment 2, the first study was replicated with a new sample of subjects, and a prior study manipulation was added. The subjects studied some but not all of the targets to be used in the priming task. During study, the targets were either presented with their primes or presented alone. In Experiment 3 , the effects of priming were explored with taxonomic category names and rhymes in both verification and lexical decision under conditions in which both prime set size and prime-to-target strength were varied. Finally, in Experiment 4, a verification task was used to evaluate the effects of using associates or rhymes as primes under conditions in which both set size and prime-to-target strength were varied.

\section{EXPERIMENT 1}

\section{Method}

Design and Subjects. The experimental design formed a $2 \times 2 \times 4$ mixed-model factorial. Type of prime (taxonomic or rhyme) was manipulated between subjects, with prime-to-target relationship (related or unrelated) and prime set size $(3-6,7-12,13-18$, or 19-30) varied within subjects. Thirty-two subjects participated in the experiment, and they were assigned so that 16 served in each condition of prime type. All subjects were recruited from courses in introductory psychology and received credit toward their grades for participation.

Apparatus. An Apple II + computer was used for stimulus presentation and data collection. The display was viewed at a distance of approximately $1 \mathrm{ft}$ so that the stimuli subtended a visual angle of approximately $7.6^{\circ}$. Reaction times were measured with a hardware timer accessed from a software program that controlled all presentations, and the timing error associated with the scanning rate of the CRT was eliminated by a software modification.

Materials. Previously developed taxonomic category norms (McEvoy \& Nelson, 1982) and rhyme norms (Nelson \& McEvoy, 1979) were used to construct the stimulus materials. Large groups 
of subjects were presented with category names or word stems and were asked to respond by writing the first category instance or rhyming word that came to mind. Single rather than multiple responses were collected to avoid problems associated with response chaining and retrieval inhibition and because the first response provides the best estimate of set size (Joelson \& Herrmann, 1978). The strength of any given instance or rhyme was estimated by calculating its relative frequency, and the set size of any given category name or word stem was estimated by calculating the total number of different but appropriate words. For example, for American Coin, responses of PENNY and DIME were among the six different words produced and were given by $20 \%$ and $14 \%$ of the subjects, respectively; for the word stem/arn/, four different rhyming words were produced, including BARN and DARN, which were given by $27 \%$ and $17 \%$ of the subjects. Both American Coin and /arn/ would be classified as having relatively small sets of related items.

These norms were used to select the 80 taxonomic and 80 rhyme categories that are shown in Appendix A. Within each type of category, there were four sets of 20 categories, with set sizes of 3-6, 7-12,13-18, and 19-30. For taxonomic categories, set size averaged $5.10(S D=1.12), 9.50(S D=1.96), 15.25(S D=1.77)$, and $24.70(S D=4.30)$, respectively, for these four set-size conditions. For the four rhyme categories, set size averaged 4.80 $(S D=1.10), 9.70(S D=1.81), 15.35(S D=1.76)$, and 21.20 $(S D=2.58)$. For each category name, two targets were selectedfor example, PENNY, DIME and BARN, DARN. One of these responses was assigned to List 1 and the other response was assigned to List 2. These assignments were made so that the average strength of association between the category name and its target was equated within each list and within each condition of set size. In other words, prime set size was not confounded with prime-to-target strength. For taxonomic categories, associative strength averaged .10 $(S D=.08)$, and for rhymes, it averaged $.09(S D=.06)$. At these levels, the responses from each type of priming category tended to consist of its more weakly related members.

The taxonomic category labels presented to the subjects in the normative task served as primes in the decision task, with the normative responses serving as the related targets. The same procedure was followed for the rhymes, except that the primary normative response (e.g., YARN) was used as the prime in place of the word stem to avoid confusions of pronunciation. Finally, two unrelated words were selected for each prime stimulus from Thorndike and Lorge (1944). Each of these unrelated words had the same frequency and was approximately of the same length as the related target to which it was yoked; for Type of Flower, for example, the related words were LILY and TULIP and the unrelated words were CHINA and OTrER. In each condition of set size, a given subject received 10 category primes paired with the related targets and a different set of 10 primes paired with the unrelated targets. This pairing was counterbalanced across subjects and lists. With this procedure, a given subject saw a particular prime only once dur- ing the experiment, but, for different subjects, the same primes were used for both related and unrelated targets-that is, a subject received Type of Flower-TULIP in the related condition, and another subject received Type of Flower-cHINA in the unrelated condition.

Procedure. A practice list of 20 trials on 10 related and 10 unrelated pairs preceded the experimental task for all subjects. None of the taxonomic or rhyme primes appearing in this task were used in the experimental task. Each trial in both tasks consisted of the following events: Two plus signs were shown on the center of the screen and were vertically positioned to indicate the location of the subsequent stimuli. They disappeared after $1 \mathrm{sec}$, and the prime appeared for $300 \mathrm{msec}$ in the position of the upper plus sign. The offset of the prime initiated a blank screen interval of $300 \mathrm{msec}$ and ended with the presentation of the test word at the location of the lower plus sign. The test word or target remained on the screen until the subject responded. In the taxonomic condition, the subjects were asked to indicate whether or not the target was an instance of the category. In the rhyme condition, they were asked to indicate whether or not the target rhymed with its prime and to ignore differences in spelling. All items were presented in uppercase letters.

The response ended the trial; if the response was incorrect, the computer signaled the error before initiating the next trial. Otherwise, the next trial was initiated immediately. The sequencing of all items in all conditions was randomized by the computer for each subject. For right-handed subjects, a "yes" response was made by pressing a marked key with the right hand, and a "no" response was indicated by pressing a marked key with the left hand. For lefthanded subjects, this procedure was reversed. With this procedure, priming effects were estimated by comparing the difference between related and unrelated pairs, and, therefore, these effects were intentionally confounded with the nature of the response ("yes"/ "no") and with handedness. Although this procedure may have enhanced the magnitude of observed priming effects because "yes" and preferred hand responses may have been faster, the procedure was the same for both types of primes and for manipulations of set size. Effects associated with type of prime and with set size should therefore not be affected by the confoundings.

\section{Results}

Reaction time. Table 1 presents the reaction times (in milliseconds) as a function of type of prime, target relatedness, and set size. Each mean is based on a maximum of 160 observations ( 16 subjects $\times 10$ primes of each type at each level of set size). Items were not treated as a random effect, because neither the primes nor the targets were selected randomly (Wike \& Church, 1976). Reaction times based on errors and on values exceeding $2,000 \mathrm{msec}$ were excluded from the calculations. Percent errors for each condition are also shown in the table, and there was

Table 1

Verification Time (VT, in Milliseconds) and Percent Error as a Function of Type of Prime, Target Relatedness, and Set Size, Experiment 1

\begin{tabular}{|c|c|c|c|c|c|c|c|c|c|}
\hline \multirow[b]{3}{*}{$\begin{array}{c}\text { Type } \\
\text { of Prime }\end{array}$} & \multirow[b]{3}{*}{$\begin{array}{c}\text { Target } \\
\text { Relatedness }\end{array}$} & \multicolumn{8}{|c|}{ Set Size } \\
\hline & & \multicolumn{2}{|c|}{$3-6$} & \multicolumn{2}{|c|}{$7-12$} & \multicolumn{2}{|c|}{$13-18$} & \multicolumn{2}{|c|}{$19-30$} \\
\hline & & VT & $\begin{array}{c}\% \\
\text { Error }\end{array}$ & VT & $\begin{array}{c}\% \\
\text { Error }\end{array}$ & VT & $\begin{array}{c}\% \\
\text { Error }\end{array}$ & VT & $\begin{array}{c}\% \\
\text { Error }\end{array}$ \\
\hline Taxonomic & $\begin{array}{l}\text { Related } \\
\text { Unrelated } \\
\text { Mean }\end{array}$ & $\begin{array}{l}892 \\
940 \\
916\end{array}$ & $\begin{array}{l}9.8 \\
3.5\end{array}$ & $\begin{array}{l}932 \\
980 \\
956\end{array}$ & $\begin{array}{l}7.8 \\
4.1\end{array}$ & $\begin{array}{l}952 \\
966 \\
959\end{array}$ & $\begin{array}{l}3.2 \\
4.8\end{array}$ & $\begin{array}{l}940 \\
972 \\
956\end{array}$ & $\begin{array}{l}4.2 \\
7.8\end{array}$ \\
\hline Rhyme & $\begin{array}{l}\text { Related } \\
\text { Unrelated } \\
\text { Mean }\end{array}$ & $\begin{array}{l}771 \\
813 \\
792\end{array}$ & $\begin{array}{l}3.6 \\
4.8\end{array}$ & $\begin{array}{l}772 \\
800 \\
786\end{array}$ & $\begin{array}{l}5.4 \\
4.3\end{array}$ & $\begin{array}{l}770 \\
825 \\
798\end{array}$ & $\begin{array}{l}5.5 \\
0.6\end{array}$ & $\begin{array}{l}793 \\
812 \\
803\end{array}$ & $\begin{array}{l}6.9 \\
4.4\end{array}$ \\
\hline
\end{tabular}


no indication that speed-accuracy tradeoffs biased the reaction time values. The correlation between mean latency and mean error rate was $r=.12$.

As can be seen in Table 1, latencies tended to be longer for taxonomic category primes than for rhyme primes. However, as measured by the difference between related and unrelated targets, the magnitude of the priming effect appeared to be essentially equivalent for the two types of primes. For taxonomic primes, mean latencies on related and unrelated targets were, respectively, 929 and $965 \mathrm{msec}$; for rhyme primes, these values were 777 and $813 \mathrm{msec}$. The analysis of variance of these sources showed that both type of prime $\left[F(1,30)=6.09, M S_{\mathrm{c}}=\right.$ $243,612]$ and target relatedness $[F(1,30)=15.91$, $\left.M S_{\mathrm{c}}=5,194\right]$ were significant, and that the interaction between these sources was not $(F<1.00)$.

The values in Table 1 also suggest that reaction times tended to increase with increasing values of prime set size. For set sizes of 3-6, 7-12, 13-18, and 19-30, average times to respond were, respectively, 854, 871, 878, and $879 \mathrm{msec}$. The effect of set size was reliable $[F(3,90)=$ $\left.7.02, M S_{e}=1,246\right]$, but it was qualified by reliable interactions with type of prime $[F(3,90)=5.00]$ and with both type of prime and target relatedness $[F(3,90)=3.90$, $\left.M S_{\mathrm{c}}=798\right]$. No other sources even approached the .05 criterion of reliability. The interaction between set size and type of prime is shown in the middle and bottom rows of the table and, as can be seen, set-size effects were essentially confined to taxonomic category primes. A Fisher's two-tailed least significant difference $(L S D)$ of $17 \mathrm{msec}$ indicated that, with taxonomic primes, reaction times were reliably faster when category size was very small compared to the remaining set-size conditions. In contrast, none of the set-size differences were reliable when the primes consisted of rhymes. The three-way interaction indicated that, within the taxonomic prime condition, setsize effects were more apparent when targets were related than when they were unrelated $(L S D=18 \mathrm{msec})$. For related targets, reaction time reliably increased from 3-6, to 7-12, to 13-18. The difference between 13-18 and 19-30 was not significant. For unrelated targets, reaction time for the smallest set was reliably faster than it was for the larger set-size conditions, which did not differ. Finally, the within-subjects $M S_{\mathrm{e}}$ terms computed separately for taxonomic and rhyme primes were 711 and $885 \mathrm{msec}$, respectively, indicating that the error variance was fairly comparable for both types of primes.

A separate analysis of the related responses (the "yes" responses) produced the same pattern of significant effects. Mean latencies were longer for taxonomic than for rhyme primes $\left[F(1,30)=5.98, M S_{\mathrm{c}}=124,539\right]$, and the effect of set size $\left[F(3,90)=8.63, M S_{\mathrm{e}}=880\right]$ and the type of prime $X$ set size interaction $[F(3,90)=5.92]$ were each significant.

Errors. Approximately 5\% of the responses were errors. Although of questionable value because of this low rate, the analysis of variance indicated that the percentage of errors was higher for related targets $(5.8 \%)$ than for unrelated targets $(4.3 \%)\left[F(1,30)=5.02, M S_{\mathrm{e}}=31\right]$. The effect of set size $\left[F(3,90)=2.78, M S_{e}=25\right]$ and the three-way interaction between type of prime, target relatedness, and set size $\left[F(3,990)=7.76, M S_{c}=24\right]$ were also reliable, but neither effect appeared to be systematically related to the manipulated variables.

\section{Discussion}

The findings from Experiment 1 replicate previous results in showing that priming effects can be obtained with taxonomic primes in the category verification task, even with relatively weak or low-dominance targets (see, e.g. Chumbley, 1986; Wilkins, 1971). The findings also show that priming effects can be obtained with rhyme in this task, but this result was to be expected, given that such effects have also been found in lexical decision, selfpaced reading, and picture-naming tasks (e.g., Hillinger, 1980; McEvoy, 1988; McNamara \& Healy, 1988; Meyer et al., 1974; Shulman, Hornak, \& Sanders, 1978; but see Martin \& Jensen, 1988, for an exception). Although rhyme judgments tended to be faster than taxonomic judgments, priming effects were equivalent for the two types of primes. This apparent equivalence, however, cannot be interpreted as indicating that the same component processes underlie judgments of taxonomic category membership and thyme.

The interaction between type of prime and set size suggests that, in contrast to what is found in extralist cued recall, different processes are likely to be involved in each domain in the verification task. Set-size effects were obtained for taxonomic but not for rhyme primes. This dissociation can be accommodated in terms of the componentprocess approach. On the assumption that set-size effects reflect the presence of a search process, the search that normally occurs for both types of primes in cued recall occurs only for taxonomic primes in the verification task.

The more generalized presence of the search component in cued recall may be related to the task requirement to produce a specified word, the studied target. This requirement presumably initiates a strategically guided search process dedicated to the recovery of a particular item, regardless of whether the process is initiated by a rhyme or the name of a taxonomic category (Nelson, 1989). In contrast, in the verification task, subjects need only verify relatedness as accurately and as quickly as possible. Any of many items can be correctly related to the prime, and subjects may or may not use the prime to anticipate the target before it appears.

This analysis is consistent with hybrid models of priming that incorporate a strategic or expectancy component (Neely, 1990). Generally speaking, these models assume that priming can be influenced by both spreading activation and strategic processing. Using network models and the concept of spreading activation as the basis, the strategic component is added, and, with this component, these models can explain the dissociation between type of prime and set size. This explanation would have to assume that the presence and absence of set-size effects is related to 
strategically induced search. With this assumption, differences in set-size effects for the two types of primes would be attributed to differences in attempts to use the prime to search the activated set to recover a related item before the target appears. Subjects working with taxonomic primes presumably use the search strategy, and, when the set is smaller, correct anticipation should be more likely and verification times should be reduced.

Several manipulations have been linked to strategic processing in verification and lexical decision tasks, including the proportion of related to unrelated pairings and the interval between onset of the prime and onset of the targetthat is, the interval known as stimulus onset asynchrony (SOA). The results of experiments in which these variables have been manipulated generally show that expectancy plays a greater role as the proportion of related pairs increases (see, e.g., Tweedy, Lapinski, \& Schvaneveldt, 1977) and as the length of the SOA increases (see, e.g., Canas, 1990; Posner \& Snyder, 1975). In the next experiment, one purpose was to investigate the effects of another variable that should affect expectancy, studying the target prior to the priming task. Such study should increase the accessibility of the target in the experimental context and should increase the probability that it will be anticipated in the presence of a related prime.

\section{EXPERIMENT 2}

In Experiment 2, the purpose was to replicate and extend the results of Experiment 1 with the same materials and a new sample of subjects. Type of prime, target relatedness, and set size were varied as in Experiment 1 . In addition, the encoding status of the target was varied prior to the verification task. Some of the related targets were studied just prior to the verification task and some were not. When related targets were studied, they were presented alone or in the presence of their primes.

Prior episodic study of the target should elevate its accessibility, especially when the prime is present, but the effects of the increased accessibility should be most apparent when subjects are attempting to anticipate the target. In this case, prior study, like set size, was expected to interact with type of prime. Prior study of the target should reduce decision latency for taxonomic but not for rhyme primes.

\footnotetext{
Method

Design and Subjects. The research design formed a $2 \times 2 \times 3 \times 4$ mixed-model factorial. Type of prime (taxonomic or thyme) and prior study condition (prime + target or target only) were manipulated between subjects. Target status on the priming task (studied, not studied but related, or unrelated) and set size (3-6, 7-12, 13-18, or 19-30) were varied within subjects. Sixty-four subjects participated, with 16 assigned to each of the four between-subjects conditions. These subjects were different from those in the previous experiment, but they were recruited from the same sources and were assigned to conditions in replication blocks.

Apparatus, Materials, and Procedure. The apparatus and materials were identical to those used in Experiment 1, as were the procedures for the priming task. The only known differences were
}

that subjects studied the targets prior to the priming task under one of two conditions, and that the priming task itself was composed of two types of related targets, those that had been studied and those that had not been studied.

During the study phase, each of the 80 targets was presented for $3 \mathrm{sec}$, either in the presence of its prime (e.g., AMERICAN COIN DIME or YARN BARN) or alone (e.g., DIME or BARN). Subjects receiving the prime and the target were told to attend to the relationship, and all subjects were told to remember as many targets as possible without being told how they would be tested. The order of all items was independently randomized for each subject.

Immediately following this study episode, subjects were introduced to the priming task, given the 20 practice trials, and then given the critical priming trials. As noted above, the procedures for this task were identical to those used previously, except that two types of related items were included-related targets that had just been studied (e.g., DIME) and related targets that were not studied during the episodic task (e.g., PENNY). The prior study condition manipulation was a pseudomanipulation for the nonstudied items. The correct response to either type of related item was "yes."

Prior study of the target was counterbalanced across subjects so that each prime was used only once for each subject. As in Experiment 1 , half of the targets within each condition of set size were unrelated to their targets. With this procedure, each reaction time mean in the unrelated and related conditions was based on a maximum of 160 observations, with studied and nonstudied related targets each based on a maximum of 80 observations. As in the previous experiment, the sequencing of all items was randomized for each subject.

\section{Results}

Reaction time. Verification time and percent error measures are presented in Table 2 for each of the principal conditions. Once again, there were no obvious indications of speed-accuracy tradeoff. The two measures tended to covary so that shorter latencies were associated with fewer errors $(r=.37)$.

As in Experiment 1, verification times were significantly longer for taxonomic primes than for rhymes $[F(1,60)=$ 59.75, $\left.M S_{\mathrm{e}}=228,760\right]$. However, the effect of target status $\left[F(1,60)=60.96, M S_{\mathrm{e}}=6,896\right]$ and the interaction between type of prime and target status $[F(2,120)=$ $10.86]$ were also significant. Verification times for the taxonomic primes were $944,1,004$, and $1,031 \mathrm{msec}$, respectively, for studied, not studied but related, and unrelated primes; for the rhyme primes, the comparable values were 705,697 , and $781 \mathrm{msec}$. An $L S D$ of $21 \mathrm{msec}$ indicated that decisions on related targets were faster than decisions on unrelated targets for both taxonomic and rhyme primes, regardless of whether the related targets were studied or not. This comparison showed that priming effects were apparent for both taxonomic and rhyme primes, but, for taxonomic primes, verification latencies were reliably faster for studied targets than for those that were not studied. In contrast, for rhyme primes, there were no differences in verification latencies for targets that were studied and those that were not. Thus, although priming effects were evident for both types of primes, prior study benefited the taxonomically related targets but not the rhyme-related targets.

The analysis of variance also indicated that prior study condition affected response time $\left[F(1,60)=9.63, M S_{\mathrm{e}}=\right.$ 
Table 2

Verification Time (VT, in Milliseconds) and Percent Error as a Function of Type of Prime, Prior Study Condition, Target Status, and Prime Set Size, Experiment 2

\begin{tabular}{|c|c|c|c|c|c|c|c|c|c|c|}
\hline \multirow{3}{*}{$\begin{array}{c}\text { Type } \\
\text { of Prime }\end{array}$} & \multirow{3}{*}{$\begin{array}{l}\text { Prior Study } \\
\text { Condition }\end{array}$} & \multirow{3}{*}{$\begin{array}{l}\text { Target } \\
\text { Status }\end{array}$} & \multicolumn{8}{|c|}{ Prime Set Size } \\
\hline & & & \multicolumn{2}{|c|}{$3-6$} & \multicolumn{2}{|c|}{$7-12$} & \multicolumn{2}{|c|}{$13-18$} & \multicolumn{2}{|c|}{$19-30$} \\
\hline & & & VT & $\%$ Ertor & VT & $\%$ Error & VT & $\%$ Error & VT & $\%$ Error \\
\hline \multirow[t]{7}{*}{ Taxonomic } & Prime and Target & Studied & 826 & 1.4 & 892 & 2.7 & 918 & 2.2 & 927 & 3.4 \\
\hline & & Not Studied & 957 & 5.2 & 967 & 6.7 & 979 & 2.2 & 1,004 & 2.0 \\
\hline & & Unrelated & 970 & 2.9 & 1,005 & 2.6 & 997 & 4.6 & 996 & 3.4 \\
\hline & Target & Studied & 973 & 6.4 & 1,015 & 6.1 & 980 & 5.5 & 1,019 & 4.2 \\
\hline & & Not Studied & 1,013 & 9.9 & 1,017 & 5.1 & 1,051 & 4.8 & 1,039 & 3.2 \\
\hline & & Unrelated & 1,039 & 1.9 & 1,079 & 4.6 & 1,067 & 4.3 & 1.093 & 3.7 \\
\hline & & Mean & 963 & & 996 & & 999 & & 1,013 & \\
\hline \multirow[t]{7}{*}{ Rhyme } & Prime and Target & Studied & 659 & 2.0 & 647 & 4.9 & 637 & 1.1 & 639 & 2.5 \\
\hline & & Not Studied & 613 & 2.7 & 616 & 4.8 & 618 & 1.0 & 637 & 1.8 \\
\hline & & Unrelated & 698 & 4.2 & 707 & 4.1 & 716 & 3.6 & 709 & 5.4 \\
\hline & Target & Studied & 784 & 0.7 & 753 & 2.1 & 735 & 2.4 & 782 & 3.0 \\
\hline & & Not Studied & 762 & 4.2 & 765 & 2.4 & 750 & 3.3 & 816 & 1.2 \\
\hline & & Unrelated & 845 & 3.5 & 859 & 2.5 & 855 & 3.7 & 851 & 2.5 \\
\hline & & Mean & 727 & & 725 & & 719 & & 739 & \\
\hline
\end{tabular}

228,760 ] such that verification latencies were faster when subjects studied the prime and target together $(806 \mathrm{msec})$ than they were when subjects studied just the target itself $(915 \mathrm{msec})$. The three-way interaction between type of prime, target status, and study condition was also significant $\left[F(2,120)=3.53, M S_{e}=6,896\right]$. For taxonomic primes, the latency advantage of studied over nonstudied targets was particularly large when the prime and target were studied together as opposed to when the target was studied by itself.

Finally, latencies tended to increase as set size increased showing average values of $845,861,859$, and $876 \mathrm{msec}$ for set sizes of 3-6, 7-12, 13-18, and 19-30. The analysis of variance indicated that set-size effects were significant $\left[F(3,180)=11.01, M S_{\mathrm{e}}=2,334\right]$, but, as in Experiment 1 , the effects of set size were qualified by an interaction with type of prime $[F(3,180)=5.81, L S D=$ 17]. This interaction is displayed in Table 2 , where it can be seen that set-size effects were apparent for taxonomic but not for rhyme primes. None of the remaining interactions involving set size or target status even approached the criterion for significance.

It should be noted that a separate analysis of only the related targets (the "yes" responses) produced the same pattern of significant effects: for type of prime, $F(1,60)=$ $62.10, M S_{\mathrm{e}}=155,740$; for study condition, $F(1,60)=$ 9.08; for target status, $F(1,60)=12.29, M S_{\mathrm{e}}=5,915$; and for set size, $F(3,180)=8.74, M S_{\mathrm{e}}=2,605$. There were also significant interactions of type of prime $\times$ target status $[F(1,60)=21.10]$, type of prime $\times$ target status $X$ study condition $[F(1,60)=8.12]$, and type of prime $\times$ set size $[F(3,180)=5.26]$. This analysis indicated that the important interactions with type of prime were apparent within just the "yes" response data. Hence, within only the related responses, prior study effects and set-size effects were limited to taxonomic primes and were not found with the rhyme primes.

Errors. The overall error rate in this experiment was very low, averaging $3.5 \%$. An analysis of variance of errors for the principal conditions showed that the only reliable sources involved three interaction effects, including type of prime $\times$ target status $\left[F(2,120)=3.08, M S_{c}=\right.$ $34]$, prior study condition $\times$ set size $[F(3,180)=3.31$, $\left.M S_{\mathrm{e}}=15\right]$, and target status $\times$ set size $[F(6,360)=4.60$, $\left.M S_{e}=17\right]$. Only the first of these interactions appeared to be systematic. Percent errors for taxonomic primes were greater than for rhyme primes for related but not for unrelated pairs. For taxonomic primes, mean percent errors were 4.0, 4.9, and 3.5, respectively, for studied, not studied, and unrelated targets; for rhyme primes, the comparable values were $2.3,2.7$, and 3.7 .

\section{Discussion}

The results of Experiment 2 replicated the main findings obtained in the initial experiment. Decisions on related targets were faster than decisions on unrelated targets for both types of prime, and set-size effects were apparent only for taxonomic primes. In addition, the results show that prior study of the target, either by itself or with its prime, shortened the time required for making verification decisions. However, as with the set-size manipulation, this effect was obtained for taxonomic but not for rhyme primes.

These findings are consistent with models in which it is assumed that priming is influenced by expectancies. Accordingly, when subjects are given a taxonomic prime, they presumably attempt to anticipate its target before it appears. This process involves searching through the set of instances activated by the prime and recovering one of them to meet the demands of the anticipation strategy. 
This strategy is likely to result in verification times that vary with both the set size of the prime and prior study of the target. Anticipation is more likely to be successful when subjects are anticipating from smaller rather than larger sets and when they have recently studied the target in the experimental context.

\section{EXPERIMENT 3}

In Experiment 3, the purpose was to determine whether the interactive effects of prime type and set size found in the verification task would be apparent in the lexical decision task. One group of subjects was asked to make verification judgments as in the previous experiments, and another was asked to make lexical decisions on the same prime-target pairs. Type of prime and prime set size were varied and crossed with the task manipulation. In addition, the primes were either strongly or weakly related to their targets in terms of normative measures. Given the results of Experiments 1 and 2, hybrid models with an expectancy component predict that, for taxonomic primes, subjects in both tasks should be more likely to anticipate the target correctly when the prime defines a smaller set. As a result, decision latencies should be shorter for taxonomic primes with smaller sets.

To the extent that strength effects are also produced by the expectancy component, strength effects should be obtained for taxonomic but not for rhyme primes. Alternatively, finding set-size effects only for taxonomic primes and strength effects for both types of primes would suggest that both expectancy and some additional process affects decision latency. This result would be interesting, because it would confirm the necessity for incorporating at least two components in models designed to explain priming effects (Neely, 1990). Set-size effects and the facilitating effects of prior study during the experimental session may be mediated by search processes associated with expectancy, and strength effects may be mediated primarily by processes associated with automatic spreading activation.

\section{Method}

Design and Subjects. For related pairs, the design formed a $2 \times 2 \times 2 \times 2$ factorial with type of prime (taxonomic or rhyme) and priming task (verification or lexical decision) manipulated between subjects, and with prime set size (small or large) and prime-to-target strength (strong or weak) varied within subjects. Twenty subjects were assigned to each of the four between-subjects conditions, and they were recruited from the same sources as in the initial study.

Materials. The 32 related primes and their targets are shown for each type of prime in Appendix B. As in Experiment 1, these items were chosen from previously obtained normative data that allowed the selection of primes on the basis of set size and prime-to-target strength (McEvoy \& Nelson, 1982). For taxonomic primes, small sets averaged $6.0(S D=1.5)$ instances and large sets averaged $19.25(S D=3.90)$ instances; strong primes averaged $.19(S D=$ $.04)$ and weak primes averaged $.03(S D=.02)$. For rhyme primes, small and large set sizes were $7.19(S D=1.90)$ and $23.87(S D=$ $5.38)$, and strong and weak primes were $.14(S D=.03)$ and .02 $(S D=.01)$, respectively. For each prime type, care was taken to equate strength within each level of set size.
This list represents the end product of a dual selection and screening procedure. Initially, two potential targets were taken for each prime at the appropriate levels of set size and strength, and the results of unprimed lexical decision tasks were used to equate the targets on reaction time. This procedure was used to control for differences in target attributes that could conceivably affect reaction time in the lexical task (Canas, 1990; de Groot, Thomassen, \& Hudson, 1982). For example, target frequency may affect decision time in the lexical decision task (see, e.g., Duchek \& Neely, 1989), and frequency and strength are often confounded, because weaker targets tend to be less frequent words (Nelson \& McEvoy, 1979).

In the unprimed tasks, 80 instances were randomly intermixed with 80 pronounceable nonwords created by replacing a single letter at random. The taxonomic and rhyme stimuli were presented to separate groups of 16 subjects, who were also different from those participating in the experimental task, and these subjects judged whether or not each letter string was a word. Mean reaction times for each word were calculated, and these values were used to select and equate the targets in the set-size-strength conditions. For the taxonomic prime condition, mean reaction times were 692 ( $S D=$ $27), 690(S D=26), 687(S D=40)$, and $691 \mathrm{msec}(S D=43)$, respectively, for the targets in the small-strong, small-weak, largestrong, and large-weak conditions. For the rhyme prime condition, the comparable values were $662(S D=23), 659(S D=30), 657$ $(S D=23)$, and $666 \mathrm{msec}(S D=22)$. For each type of prime, this procedure ensures that differences associated with set size and strength in the lexical decision task are due to prime-target relationships and not to characteristics of the targets themselves. As another precaution, an attempt was made to control target length within each prime type condition, with taxonomic and rhyme targets containing an average of $5.42(S D=1.52)$ and $4.38(S D=.91)$ letters over the various set-size-strength conditions.

For the primed lexical decision tasks, 8 additional prime-target pairs served as unrelated pairs, and these items were completely different from those used for related items-for example, MUSICAL INSTRUMENT PITCHFORK was added to the taxonomic list and ARROW RIDDLE was added to the rhyme list. This addition produced lists of 40 pairs constructed so that $80 \%$ of these pairs were related and $20 \%$ were unrelated. Another 40 primes were selected from the taxonomic and rhyme norms to serve as primes for the nonwords. These primes were different from all others, so that no prime was repeated. Forty nonwords were selected from the pool of nonwords used in the nonprimed lexical decision tasks and were paired randomly with the primes. Finally, all subjects given the lexical decision task received a practice list of 80 pairs prior to the experiment. None of the items in the practice list overlapped with those of the experimental list, but, as on that list, there were 32 related pairs, 8 unrelated pairs, and 40 nonword pairs.

For the verification task, the unrelated pairs were formed by selecting 32 primes and pairing them with unrelated targets from other unused categories-for example, CARPENTER'S TOOL CLOWN. These targets contained an average of $6.59(S D=1.78)$ letters. The subjects were given a practice list, and, like the experimental list, it contained 64 pairs, half of which were related and required a "yes" response and half of which were unrelated and required a "no" response.

Procedure and Apparatus. The apparans, the timing of events, and the general procedures were identical to those in Experiments 1 and 2 . The only difference consisted in the meaning of the responses in the two tasks. A "yes" response in the verification task indicated that the prime and target were related, whereas, in the lexical decision task, it indicated that the target following the prime was a word. A "no" response indicated that the prime and target were unrelated or that the target was not a word. The sequencing of all pairs in both tasks was randomized by the computer, and the randomization was changed for each subject. Because of a programming error, no data could be obtained on the CHARM FARM rhyme pairing in the small-weak condition in both 
tasks. Performance in this condition was therefore based only on the remaining rhyme pairs in this condition

\section{Results}

Table 3 displays the mean reaction times (and percent errors) for the two tasks as a function of type of prime, prime set size, and prime strength. Each mean is based on a maximum of 160 observations (20 subjects $\times 8$ primes). As in the previous experiments, there appeared to be no evidence for speed-accuracy tradeoff effects, and the mean latencies and errors shown in the table tended to covary $(r=.73)$.

The latency values for related and unrelated pairs suggested that priming effects were obtained in each task for both types of primes. Orthogonal contrasts were made between the combined related conditions and the unrelated condition for each type of prime and task, and these comparisons showed that response latencies were significantly faster for related than for unrelated pairs in each case. The $F \mathrm{~s}(1,304)$ were $10.97,7.94,8.49$, and $8.39\left(M S_{\mathrm{e}}=\right.$ 7,306 ), respectively, for taxonomic verification, taxonomic lexical decision, rhyme verification, and rhyme lexical decision. Reliable priming effects were obtained for each type of prime in each task.

Because interest was focused on the relative effects of set size and strength within each type of prime and task, the main statistical analysis focused on the related primes. As can be seen in Table 3, response latencies tended to be shorter when the prime defined smaller, as opposed to larger, sets. However, as in Experiments 1 and 2, these set-size effects were apparent for taxonomic primes, but not for rhyme primes. For rhymes, set size tended to have no effect or, if anything, it had a slightly reversed effect. Furthermore, this interactive pattern was as apparent in the lexical decision task as it was in the verification task. The results of the analysis of variance of related pairs indicated that set size $\left[F(1,76)=3.96, M S_{\mathrm{e}}=4,448\right]$ and the interaction between set size and type of prime $[F(1,76)=$ 12.08] were significant, and that the effects of task $[F(1,76)=1.98]$ and all interactions involving task and type of prime or set size were not significant. Mean response latencies for small and large taxonomic primes were, respectively, 694 and $735 \mathrm{msec}$; for small and large rhyme primes, these values were 664 and $653 \mathrm{msec}$. A Fisher's $L S D$ of $21 \mathrm{msec}$ indicated that reliable set-size effects were apparent only for taxonomic primes.

The other finding of importance in Table 3 concerns the effects of normatively defined prime strength. Response latencies for stronger prime-target relationships tended to be faster than those for weaker relationships in every comparison, producing a reliable effect of strength $[F(1,76)=$ $59.75, M S_{c}=4,365$ ]. Although there was a tendency for this effect to be more apparent in verification than in lexical decision, this tendency did not result in a reliable interaction between strength and task $[F(1,76)=3.55, p<$ .06]. Simple effect examination of this interaction showed that strength significantly affected decision time in each task. Finally, although rhyme decisions tended to be faster than taxonomic decisions, but not significantly faster $\left[F(1,76)=3.16, M S_{\mathrm{e}}=79,235\right]$, strength effects were as apparent for rhyme as for taxonomic primes. No other sources even approached the criterion for significance.

Percent errors are also shown in Table 3, and, as in the previous experiments, there were few errors and many scores of zero, with errors averaging $3.8 \%$ across the related conditions. However, as indicated in the table, more errors occurred in the verification task $(6.1 \%)$ than in the lexical decision task (1.5\%). This was the only reliable difference $\left[F(1,76)=20.52, M S_{\mathrm{e}}=81\right]$.

\section{Discussion}

The results of Experiment 3 demonstrated priming effects for both taxonomic and rhyme primes in both verification and lexical decision tasks. The results also replicated the interaction between type of prime and prime set size found in Experiments 1 and 2, extending this finding to the lexical decision task. Taxonomic primes that theoretically activate relatively small sets of instances produce faster verifications and lexical decisions than those that prime relatively large sets of instances. In contrast, set-size effects are not found for rhyme primes in either task.

The results of Experiment 3 also showed that both verification and lexical decisions were faster for stronger

Table 3

Reaction Time (RT, in Milliseconds) and Percent Error as a Function of Type of Prime, Type of Task, Prime Strength, and Prime Set Size, Experiment 3

\begin{tabular}{|c|c|c|c|c|c|c|c|c|c|c|}
\hline \multirow[b]{3}{*}{$\begin{array}{c}\text { Type } \\
\text { of Prime }\end{array}$} & \multirow[b]{3}{*}{$\begin{array}{c}\text { Type } \\
\text { of Task }\end{array}$} & \multirow[b]{3}{*}{$\begin{array}{c}\text { Prime } \\
\text { Strength }\end{array}$} & \multicolumn{8}{|c|}{ Prime Set Size } \\
\hline & & & \multicolumn{2}{|c|}{ Small } & \multicolumn{2}{|c|}{ Large } & \multicolumn{2}{|c|}{ Unrelated } & \multicolumn{2}{|c|}{ Nonword } \\
\hline & & & $\mathrm{RT}$ & $\begin{array}{c}\% \\
\text { Error }\end{array}$ & RT & $\begin{array}{c}\% \\
\text { Error }\end{array}$ & RT & $\begin{array}{c}\% \\
\text { Error }\end{array}$ & RT & $\begin{array}{c}\% \\
\text { Error }\end{array}$ \\
\hline \multirow[t]{2}{*}{ Taxonomic } & Verification & $\begin{array}{l}\text { Strong } \\
\text { Weak }\end{array}$ & $\begin{array}{l}700 \\
774\end{array}$ & $\begin{array}{l}6.8 \\
8.1\end{array}$ & $\begin{array}{l}736 \\
805\end{array}$ & $\begin{array}{l}6.8 \\
8.1\end{array}$ & 818 & 9.1 & & \\
\hline & Lexical Decision & $\begin{array}{l}\text { Strong } \\
\text { Weak }\end{array}$ & $\begin{array}{l}617 \\
686\end{array}$ & $\begin{array}{l}0.6 \\
4.3\end{array}$ & $\begin{array}{l}673 \\
725\end{array}$ & $\begin{array}{l}0.6 \\
2.5\end{array}$ & 815 & 14.0 & 792 & 3.3 \\
\hline \multirow[t]{2}{*}{ Rhyme } & Verification & $\begin{array}{l}\text { Strong } \\
\text { Weak }\end{array}$ & $\begin{array}{l}633 \\
702\end{array}$ & $\begin{array}{l}9.4 \\
4.3\end{array}$ & $\begin{array}{l}624 \\
696\end{array}$ & $\begin{array}{l}2.4 \\
3.1\end{array}$ & 722 & 3.6 & & \\
\hline & Lexical Decision & $\begin{array}{l}\text { Strong } \\
\text { Weak }\end{array}$ & $\begin{array}{l}640 \\
682\end{array}$ & $\begin{array}{l}0.0 \\
1.2\end{array}$ & $\begin{array}{l}642 \\
650\end{array}$ & $\begin{array}{l}1.8 \\
1.2\end{array}$ & 695 & 2.6 & 773 & 2.3 \\
\hline
\end{tabular}


than for weaker prime-to-target relationships. This effect was as apparent for rhyme as it was for taxonomic primes. The strength effect found for taxonomic primes replicates previous findings obtained with meaningfully related stimuli in both tasks (see, e.g., Canas, 1990; Chumbley, 1986; de Groot et al., 1982; Neely, 1977). The strength effect obtained with rhymes represents a new finding in the priming literature, but not in the memory cuing literature, where such effects have been replicated many times (see, e.g., Nelson, 1989; Nelson et al., 1982). Because targets were equated in the unprimed lexical decision task prior to the experiment, it would be hard to attribute strength effects to factors other than the availability of the priming stimulus.

Theoretically, the presentation of the prime activates related concepts, and such activation explains the presence of strength effects for both types of primes. Stronger targets presumably receive more activation from the prime than weaker targets do. In contrast, the presence of setsize effects for taxonomic primes, as well as their absence with rhyme primes, can be attributed to differential attempts to anticipate the target before it appeared. This account is consistent with hybrid models of priming (e.g., that of Neely, 1990). Strength effects are attributed primarily to the amount of activation accruing to the target as a function of the presence of the prime, and setsize effects are attributed to sampling processes linked to the likelihood of one's correctly anticipating the target.

\section{EXPERIMENT 4}

The rhyme results of Experiment 3 indicated that normatively defined strength effects can be present in the absence of set-size effects, suggesting that different processes may underlie each effect. In Experiment 4, the primary purpose was to replicate this dissociation. Type of prime was crossed with prime-to-target strength and prime set size in a verification task. For related pairs, the primes consisted of either meaningful associates or rhymes. Both types of primes should produce faster decisions for related than for unrelated pairs, and the question was whether the presence of strength effects would be independent of the presence of set-size effects. The independent occurrence of these effects would suggest that strength effects are being mediated by processes other than expectancy, such as automatic activation. In other words, when subjects are attempting to anticipate the target, set-size and strength effects are likely, and, when they are not attempting to anticipate the target, strength but not set-size effects are likely. This interpretation is based on the assumption that set-size effects reflect strategically induced search processes, whereas strength effects are more likely to reflect processes associated with automatic access.

A second purpose in Experiment 4 was to use meaningful associates in place of taxonomic category primes to help determine why set-size effects were found with taxonomic but not with rhyme primes. If set-size effects are obtained with taxonomic primes because subjects are more used to anticipating meaningfully related concepts, then set-size effects should be obtained for associatively related primes. Both taxonomic and associative primes are meaningfully related to their targets. Alternatively, if setsize effects are found for taxonomic primes because they represent higher order cues, then set-size effects may not be obtained for associates. With associates, subjects may not be as able to anticipate the upcoming target under the conditions used in this experiment.

\section{Method}

Design and Subjects. One half of the prime-target pairings were unrelated, and the remaining one half were related. The related pairs formed a $2 \times 2 \times 2$ factorial, with type of prime (meaning or rhyme) varied between subjects and prime-to-target strength (strong or weak) and set size (small or large) manipulated within subjects. Twenty subjects were given meaning primes, and another 20 subjects were given rhyme primes.

Materials. The related pairs representing each condition of set size and strength for both types of primes are shown in Appendix C. These materials were selected from previously described meaning and rhyme norms (Nelson \& McEvoy, 1979). Two different related lists were created for each prime type, with 80 related pairs represented in each list, 20 for small-strong, 20 for small-weak, and so forth. The words serving as strong primes in List 1 served as weak primes in List 2. With this procedure, the primes for strong and weak targets were identical. For the meaning primes, small and large prime set sizes averaged, respectively, $7.32(S D=1.47)$ and $16.78(S D=1.60)$ associates; for rhymes, these values were $6.07(S D=1.79)$ and $16.23(S D=2.27)$. Prime-to-target strength for meaning primes averaged $.38(S D=.08)$ for strong relationships and $.08(S D=.03)$ for weak relationships; the comparable values for rhyme primes were $.27(S D=.09)$ and $.06(S D=.03)$. For each prime type and list, the strength manipulation was equated at each level of set size.

The 80 unrelated pairs were created by selecting 160 words with printed frequencies similar to those of the primes and targets and randomly pairing them. The same unrelated list was used for both types of prime. The 80 unrelated pairs were randomly intermixed with the 80 related pairs for presentation, and this ordering was changed for each subject.

Procedure and Apparatus. The apparatus and general procedures were identical to those used for the verification task in the previous experiments. However, because the meaning primes contained fewer letters than the taxonomic primes used in the previous experiments, the SOA was reduced to $500 \mathrm{msec}$. The primes remained in view until the target appeared. Each subject received only one list, and list was counterbalanced across subjects in the rhyme and meaning conditions.

\section{Results}

Table 4 displays the mean verification latencies (and percent errors) as a function of type of prime, prime strength, and prime set size. Each mean was based on a maximum of 400 observations ( 20 subjects $\times 20$ primes) for the related pairs and on a maximum of 1,600 observations ( 20 subjects $\times 80$ primes) for the unrelated pairs. Numerically fewer errors were obtained for strong than for weak primes, but, because there was such a low percentage of errors in some conditions, these data were not analyzed further.

Orthogonal contrasts comparing the combined related conditions with the unrelated condition for each type of 
Table 4

Verification Time (VT, in Milliseconds) and Percent Error as a Function of Type of Prime, Prime Strength, and Prime Set Size, Experiment 4

\begin{tabular}{|c|c|c|c|c|c|c|c|}
\hline \multirow[b]{3}{*}{$\begin{array}{c}\text { Type } \\
\text { of Prime }\end{array}$} & \multirow[b]{3}{*}{$\begin{array}{l}\text { Prime } \\
\text { Strength }\end{array}$} & \multicolumn{4}{|c|}{ Prime Set Size } & & \\
\hline & & \multicolumn{2}{|c|}{ Small } & \multicolumn{2}{|c|}{ Large } & \multicolumn{2}{|c|}{ Unrelated } \\
\hline & & VT & $\begin{array}{c}\% \\
\text { Error }\end{array}$ & VT & $\begin{array}{c}\% \\
\text { Error }\end{array}$ & VT & $\begin{array}{c}\% \\
\text { Error }\end{array}$ \\
\hline \multirow[t]{2}{*}{ Meaning } & Strong & 843 & .00 & 862 & .04 & 1,141 & .06 \\
\hline & Weak & 983 & .12 & 997 & .09 & & \\
\hline \multirow[t]{2}{*}{ Rhyme } & Strong & 583 & .00 & 575 & .02 & 653 & .03 \\
\hline & Weak & 648 & .03 & 616 & .05 & & \\
\hline
\end{tabular}

prime showed that decisions were significantly faster for related pairs. The $F \mathrm{~s}(1,152)$ were 5.59 and $11.25\left(M S_{\mathrm{e}}=\right.$ $9,304)$, for rhyme and meaning primes, respectively.

The values shown in the table also show that, for related pairs, rhyme decisions tended to be faster than meaning decisions, and set-size effects were small and inconsistently obtained whereas strength effects were evident in all conditions. A statistical analysis of the related primes indicated that type of prime $\left[F(1,38)=35.18, M S_{\mathrm{e}}=\right.$ $113,512]$, and strength $\left[F(1,38)=45.29, M S_{\mathrm{e}}=7,972\right]$, were reliable sources of variance. This analysis also indicated that the type of prime $\times$ strength interaction was significant $[F(1,38)=8.94]$. For meaning primes, mean latencies for strong and weak primes were, respectively, 853 and $990 \mathrm{msec}$; for rhymes, these values were 579 and $632 \mathrm{msec}$. A Fisher's $L S D$ of $40 \mathrm{msec}$ indicated, however, that significant strength effects were apparent for each type of prime, indicating that the interaction reflected differences in degree rather than differences in kind. Finally, prime set size failed to have an effect $(F<1.00)$, and, although set size appeared to have slight reversed effects for meaning and rhyme primes, the interaction between type of prime and set size was not reliable $(F=3.04)$. An $L S D$ of $30 \mathrm{msec}$ indicated that set size had no reliable effect within either type of prime.

\section{Discussion}

The results of Experiment 4 agree with those of all three previous experiments in showing that set-size effects were not found for rhyme-related primes. The results of this experiment also showed that only small and insignificant set-size effects were found for meaning primes. The absence of set-size effects for both rhyme and meaningfully related primes agrees well with the results of other experiments that were completed as part of this series but that are not presented here to conserve space. Priming effects were found in three other lexical decision studies and one verification experiment, but set-size effects were not found for either type of prime in any of these experiments. One of the lexical decision experiments was run with a very long SOA of $1,500 \mathrm{msec}$. Throughout this long project, such effects were expected to emerge under the "right" set of conditions, and they still may emerge, but after eight independent attempts to find rhyme set-size effect and five such attempts to demonstrate associative set-size effects in priming tasks, such effects seem unlikely.

The most interesting result associated with Experiment 4 is that strength effects emerged in the absence of consistent set-size effects. Decision latencies were shorter for stronger than for weaker rhymes, as in Experiment 3, and they were also shorter for stronger than for weaker associates. Normatively defined prime-to-target strength effects are not contingent on the presence of set-size effects. One implication of this finding is that the processes responsible for producing set-size effects may be different from those that result in strength effects. As has been suggested, set-size effects appear to be related to expectancies that emerged only for taxonomic primes. Under the conditions of this series of experiments, strength effects appear to have been mediated primarily by processes associated with spreading activation.

\section{GENERAL DISCUSSION}

The results of these experiments are consistent with previous findings that demonstrate priming effects for taxonomic, rhyme, and associatively related primes. However, although these primes respond in the same way to manipulations of normatively measured strength, they respond differently to manipulations of set size and prior study. For taxonomic primes, the present findings indicate that decision latency is shorter when the prime defines a smaller set and when the target is studied prior to the decision task, especially when it is studied directly with the prime. In contrast, for rhyme primes, neither set size nor prior study affected decision time, and, for associates, set size had no effect.

These interactions with type of prime can be explained in terms of the component-process approach (Jacoby, 1983; Nelson, Canas, Bajo, \& Keelean, 1987; Nelson et al., 1989; Roediger \& Blaxton, 1987). The presence of set-size and prior study effects for taxonomic primes can be attributed to strategically induced search processes, and the presence of strength effects for all primes can be attributed to automatic access processes. This explanation is consistent with hybrid models of priming effects that incorporate an expectancy assumption with a spreading activation assumption (see, e.g., Neely, 1990; Posner \& Snyder, 1975). Because they incorporate expectancy, hybrid models allow for the possibility of interactions between type of prime or type of task with other variables, depending on the strategy that subjects develop during the experimental episode. The set-size findings obtained in the present experiments can be explained by assuming that the subjects working with different types of primes developed different strategies for reaching decisions. Under the present conditions, subjects appeared to develop a strategy of anticipating taxonomically primed instances, whereas subjects working with rhymes and associates either did not use this strategy or used it so infrequently that set-size effects never emerged for these primes. The 
development of differences in strategy for different primes appears reasonable, on the assumption that taxonomic category names are special in some sense. They are higher order cues that provide a name for a collection of instances that are likely to be highly accessible to the majority of the subjects. As higher order cues, they are not members of the set, and, in comparison with rhymes and associates, taxonomic cues may be less likely to engender retrieval inhibition (Nelson et al., 1982).

The dissociation of set-size and normative strength effects for the three types of primes also has implications for interpretations of cued recall findings. In the extralist cued recall task, taxonomic, rhyme, and associatively related test cues show parallel effects of set size and strength under a variety of study and test conditions (see, e.g., Nelson, 1989). Difficulties encountered in attempts to find variables that interact with either strength or set size in the cued recall task suggest that this task may not be well suited for determining whether these effects are produced by the same or by different component processes. The parallel effects of these variables could mean that both strength and set-size effects are produced through automatic activation, with strong cues and those activating smaller sets producing more activation for the representation of the target than weaker cues and those activating larger sets (see, e.g., Anderson, 1983). Alternatively, the cued recall findings could mean that both effects are produced by sampling processes such that stronger targets and those that are members of smaller sets are more likely to be sampled (Nelson, 1989; Raaijmakers \& Shiffrin, 1981).

In contrast to either of these views, the priming results obtained in these experiments suggest that set-size effects may be produced by one of these processes with strength effects produced by the other. Search and sampling processes appear to underlie set-size effects in both priming and cued recall tasks. In contrast, the automatic activation process appears to underlie the effects of normatively defined strength, and this process may also be involved in producing strength effects in cued recall. Automatic activation, however, may not be the only process underlying strength effects in these two tasks. At SOAs longer than those used in the present experiments, the magnitude of observed strength effects for associatively related primes is sensitive to variables that affect strategic processing (Canas, 1990). At longer SOAs, the effects of strength appear to be produced both by automatic spreading activation and by search and sampling processes. Given that the cued recall task is typically self-paced, cueto-target strength effects observed in this task may also be produced by both processes.

The dissociations involving type of prime illustrate a potential advantage of the component processing approach when comparisons are made between the effects of the same variables in different tasks. The absence of dissociations among the variables in one task provides no useful information for making decisions about whether the same or different processes underlie the effects of the variables in that task. The presence of dissociations among the same variables in a contrasting task, however, suggests that different component processes may underlie the effects of each variable in both tasks. Dissociative effects obtained in one type of retention test can be used to make inferences about component processes underlying the effects of the same variables in another type of test. There are, however, limits to this advantage. This approach is not without risk, because it assumes that the nature of the component processes do not undergo qualitative changes in different tasks. For example, given that a search through preexisting memories occurs in a particular task, the nature of the search is presumed to be the same, regardless of whether the search occurs in a cued recall or in a priming task. The assumption of task-independent processing components may be too strong, but, if it proves to be correct, exploring the effects of the same variables in different tasks should provide a fruitful means for understanding the general nature of various component processes as well as the tasks under consideration. On the contrary, the failure of this assumption would place severe restrictions on the general theoretical utility of the componentsof-processing approach. Although the approach would remain useful for understanding components of processing within a specific task, comparisons of components across tasks would normally not be justified.

\section{REFERENCES}

ANDERSON, J. R. (1983). Language, memory, and thought. Hillsdale, NJ: Erlbaum.

Canas, J. J. (1990). Associative strength effects in the lexical decision task. Quarterly Journal of Experimental Psychology: Human Experimental Psychology, 42, 121-145.

Chang, T. M. (1986). Semantic memory: Facts and models. Psychological Bulletin, 99, 199-220.

Chumbley, J. I. (1986). The roles of typicality, instance dominance, and category dominance in verifying category membership. Journal of Experimental Psychology: Learning, Memory, \& Cognition, 12 , 257-267.

Cohen, N. J., \& Squire, L. R. (1980). Preserved learning and retention of pattern-analyzing skill in amnesia: Dissociation of "knowing how" and "knowing that." Science, 210, 207-209.

de Groot, A. M. B., Thomassen, A. J. W. M., Hudson, P. T. W. (1982). Associative facilitation of word recognition as measured from a neutral prime. Memory \& Cognition, 10, 358-370.

DucheK, J. M., \& NeELY, J. H. (1989). A dissociative word-frequency $\times$ levels-of-processing interaction in episodic recognition and lexical decision tasks. Memory \& Cognition, 17, 148-162.

Graf, P., \& Mandler, G. (1984). Activation makes words more accessible, but not necessarily more retrievable. Joumal of Verbal Learning \& Verbal Behavior, 23, 553-568.

GraF, P., \& SCHACTER, D. L. (1987). Selective effects of interference on implicit and explicit memory for new associations. Journal of Experimental Psychology: Learning, Memory, \& Cognition, 13, 45-53.

Hillinger, M. L. (1980). Priming effects with phonemically similar words: The encoding-bias hypothesis reconsidered. Memory \& Cognition, 8, 115-123.

JACOBY, L. L. (1983). Perceptual enhancement: Persistent effects of an experience. Journal of Experimental Psychology: Learning, Memory, \& Cognition, 9, 21-38.

JACOBY, L. L. \& DALLAS, M. (1981). On the relationship between autobiographical memory and perceptual learning. Joumal of Experimental Psychology: General, 110, 306-340.

Joelson, J. M., Herrmann, D. J. (1978). Properties of categories in semantic memory. American Journal of Psychology, 91, 101-114. 
Light, L. L., \& SiNGH, A. (1987). Implicit and explicit memory in young and older adults. Journal of Experimental Psychology: Learning, Memory, \& Cognition, 13, 531-541.

Martin, R. C., \& Jensen, C. R. (1988). Phonological priming in the lexical decision task: A failure to replicate. Memory \& Cognition, 16, 505-521.

McEvor, C. L. (1988). Automatic and strategic processes in picture naming. Journal of Experimental Psychology: Learning, Memory, \& Cognition, 14, 618-626.

McEvoy, C. L., \& Nelson, D. L. (1982). Category name and instance norms for 106 categories of various sizes. American Joumal of Psychology, 95, 581-634.

McNamara, T. P., \& Healy, A. F. (1988). Semantic, phonological, and mediated priming in reading and lexical decision. Journal of $E x$ perimental Psychology: Leaming, Memory, \& Cognition, 14, 398-409.

Meyer, D. E., Schvaneveldt, R. W., \& Ruddy, M. G. (1974). Functions of graphemic and phonemic codes in visual word-recognition. Memory \& Cognition, 2, 309-321.

NeELy, J. H. (1977). Semantic priming and retrieval from lexical memory: Roles of inhibitionless spreading activation and limitedcapacity attention. Journal of Experimental Psychology: General, 106, 226-254.

Neely, J. H. (1990). Semantic priming effects in visual word recognition: Selective review of current findings and theories. In D. Besner \& G. Humphreys (Eds.), Basic processes in reading: Visual word recognition. Hillsdale, NJ: Erlbaum.

NeLSON, D. L. (1989). Implicitly activated knowledge and memory. In C. Izawa (Ed.), Current issues in cognitive process: The Tulane Floweree Symposium on cognition (pp. 367-387). Hillsdale, NJ: Erlbaum.

Nelson, D. L., Canas, J., \& Bajo, M.-T. (1987). The effects of natural category size on memory for episodic encodings. Memory \& Cognition, 15, 133-140.

Nelson, D. L., Canas, J. J., Bajo, M.-T., \& Kelelean, P. D. (1987). Comparing word fragment completion and cued recall with letter cues. Joumal of Experimental Psychology: Learning, Memory, \& Cognition, 13, 542-552.

Nelson, D. L., Keelean, P. D., \& Negrao, M. (1989). Word-fragment cuing: The lexical search hypothesis. Joumal of Experimental Psychology: Learning, Memory, \& Cognition, 15, 388-397.
Nelson, D. L.. \& McEvoy, C. L. (1979). Encoding context and set size. Joumal of Experimental Psychology: Human Learning \& Memory, 5, 292-314.

Nelson, D. L., McEvoy, C. L., Baso, M.-T. (1988). Lexical and semantic search in cued recall, fragment completion, perceptual identification, and recognition. American Joumal of Psychology, 101. 465-480.

Nelson, D. L., McEvoy, C. L., \& Friedrich, M. A. (1982). Extra list cuing and retrieval inhibition. Joumal of Experimental Psychology: Learning, Memory, \& Cognition, 8, 89-105.

Posner, M. I., SNyder, C. R. R. (1975). Attention and cognitive control. In R. L. Solso (Ed.), Information processing and cognition: The Loyola Symposium (pp. 55-85). Hillsdale, NJ: Erlbaum.

RaAijmakers, J. G. W., \& Shiffrin, R. M. (1981). Search of associative memory. Psychological Review, 88, 454-462.

Roediger, H. L., III, \& BLAXTON, T. A. (1987). Effects of varying modality, surface features, and retention interval on priming in wordfragment completion. Memory \& Cognition, 15, 379-388.

Shulman, H. G., Hornak, R., \& Sanders, E. (1978). The effects of graphemic, phonetic, and semantic relationships on access to lexjcal structures. Memory \& Cognition, 6, 115-123.

Squire, L. R., Shimamura, A., \& Graf, P. (1985). Independence of recognition memory and priming effects: A neuropsychological analysis. Joumal of Experimental Psychology: Leaming, Memory, \& Cognition, 11, 37-44

THORNDIKE, E. L., \& LORGE, I. (1944). The teacher's word book of 30,000 words. New York: Columbia University Press.

Tulving, E. (1985). How many memory systems are there? American Psychologist, 40, 385-398.

Tweedy, J. R., Lapinski, R. H., Schvaneveldt, R. W. (1977). Semantic-context effects on word recognition: Influence of varying the proportion of items presented in an appropriate context. Memory \& Cognition, 5, 84-99

Wike, E. L., \& Church, J. D. (1976). Comments on Clark's "Thelanguage-as-fixed-effect-fallacy. " Journal of Verbal Leaming \& Verbal Behavior, 15, 249-255.

WILKINS, A. J. (1971). Conjoint frequency, category size, and categorization time. Journal of Verbal Learning \& Verbal Behavior, 10 , 382-385.

Appendix A

Materials Used in Experiments 1 and 2

\begin{tabular}{|c|c|c|c|c|c|}
\hline \multirow{2}{*}{$\begin{array}{c}\text { Prime } \\
\text { Set } \\
\text { Size } \\
\end{array}$} & \multirow[b]{2}{*}{ Prime } & \multicolumn{2}{|c|}{ List 1} & \multicolumn{2}{|c|}{ List 2} \\
\hline & & Related & Unrelated & Related & Unrelated \\
\hline \multicolumn{6}{|c|}{ Taxonomic Category Primes and Targets } \\
\hline \multirow[t]{20}{*}{$3-6$} & AMERICAN COIN & PENNY & COCAINE & DIME & TADPOLE \\
\hline & BRANCH OF ARMED SERVICES & NAVY & PILLOW & ARMY & PIECES \\
\hline & PART OF AN ATOM & NEUTRON & PEDAL & ELECTRON & SIOUX \\
\hline & MUSICAL BRASS INSTRUMENT & TUBA & MOUSE & TROMBONE & NATURAL \\
\hline & CITRUS FRUIT & LEMON & LOBSTER & LIME & FOG \\
\hline & COLLEGE LEVEL & JUNIOR & CATHOLIC & SENIOR & BANKER \\
\hline & DAILY MEAL & DINNER & DOG & BREAKFAST & HEART \\
\hline & TYPE OF DRUM & KETTLE & WATER & SNARE & MANURE \\
\hline & EATING UTENSIL & SPOON & MINK & KNIFE & СОMET \\
\hline & KIND OF EXPLOSIVE & T.N.T. & BED & NITRO & LOCAL \\
\hline & PART OF FACE & CHEEK & MAN & MOUTH & NUTRIENTS \\
\hline & INSECT THAT STINGS & HORNET & CLOWNS & WASP & CHAIN \\
\hline & MATHEMATICAL OPERATION & DIVISION & RUNNING & MULTIPLICATION & HIERARCHY \\
\hline & MAJOR TYPE OF MEAT & PORK & SHOES & LAMB & CRAWL \\
\hline & PRIMARY COLOR & GREEN & BROOM & YELLOW & SMORGASBORD \\
\hline & MEMBER OF ROYALTY & PRINCE & CHERRY & DUKE & SPACE \\
\hline & SEASON OF THE YEAR & WINTER & ENGINE & SUMMER & ABDOMEN \\
\hline & TYPE OF SINGING VOICE & ALTO & WING & TENOR & BOULDER \\
\hline & A TIMEPIECE & HOURGLASS & STRAWBERRY & SUNDIAL & SUPERMAN \\
\hline & BRANCH OF U.S. GOVERNMENT & EXECUTIVE & MICROSCOPE & LEGISLATIVE & CONVERTIBLE \\
\hline
\end{tabular}


Appendix A (Continued)

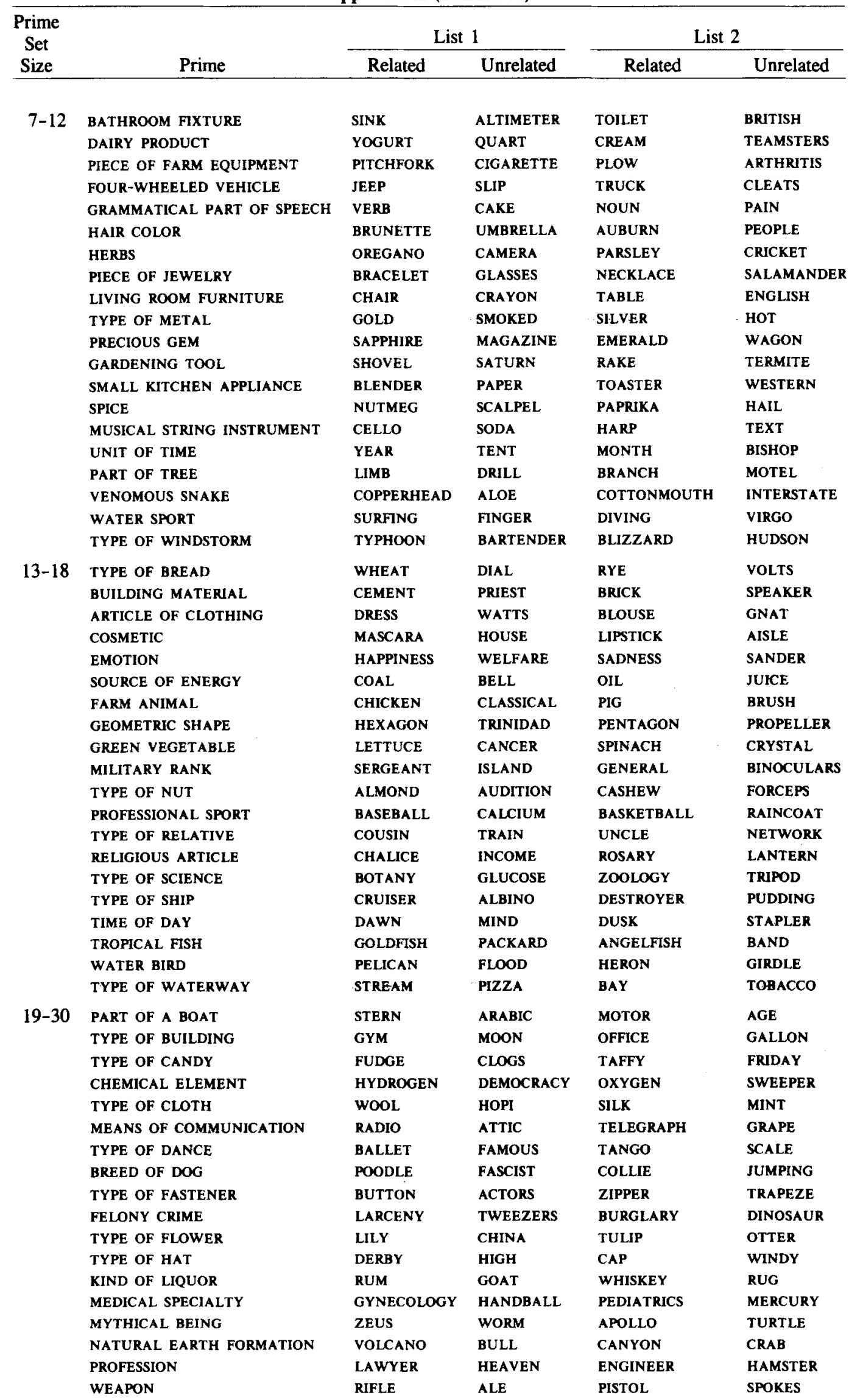


Appendix A (Continued)

\begin{tabular}{|c|c|c|c|c|c|}
\hline \multirow{2}{*}{$\begin{array}{c}\text { Prime } \\
\text { Set } \\
\text { Size }\end{array}$} & \multirow[b]{2}{*}{ Prime } & \multicolumn{2}{|c|}{ List 1} & \multicolumn{2}{|c|}{ List 2} \\
\hline & & Related & Unrelated & Related & Unrelated \\
\hline & WILD ANIMAL & WOLF & COLD & COYOTE & SPREAD \\
\hline & KIND OF WOOD & REDWOOD & ADRIATIC & MAPLE & ASPIRIN \\
\hline \multicolumn{6}{|c|}{ Rhyme Primes and Targets } \\
\hline \multirow[t]{20}{*}{$3-6$} & YARN & BARN & BRANCH & DARN & $\operatorname{TAX}$ \\
\hline & HARP & CARP & HIGH & SHARP & STRANGE \\
\hline & TASK & BASK & PLAY & FLASK & FLAG \\
\hline & HARD & GUARD & HORN & CARD & GAVE \\
\hline & MESH & FLESH & MOVE & FRESH & MELD \\
\hline & BENCH & STENCH & LEDGE & WRENCH & LUNCH \\
\hline & MILK & BILK & MISS & SILK & MUSH \\
\hline & LISP & WISP & LIFT & CRISP & LAUNCH \\
\hline & KNIFE & WIFE & FIB & STRIFE & KIND \\
\hline & RIDGE & BRIDGE & RINSE & FRIDGE & RISK \\
\hline & $\operatorname{COIN}$ & JOIN & JOINT & LOIN & Cove \\
\hline & HOOD & GOOD & HOIST & WOOD & HOUSE \\
\hline & ROACH & $\mathrm{COACH}$ & ROOF & POACH & ROAM \\
\hline & POUNCE & TROUNCE & PORK & BOUNCE & POUND \\
\hline & BULK & SULK & DUKE & HULK & BUT \\
\hline & TUSK & HUSK & THUD & DUSK & TOUCH \\
\hline & FIRST & WORST & FLUX & THIRST & FARCE \\
\hline & WORM & TERM & WATCH & GERM & WORK \\
\hline & LOBE & PROBE & LOOK & STROBE & LOYAL \\
\hline & GRASP & RASP & CHARM & GASP & RAPT \\
\hline \multirow[t]{20}{*}{$7-12$} & LAUGH & CALF & STARCH & HALF & FAITH \\
\hline & PAGE & STAGE & BAR & CAGE & PAINT \\
\hline & FAST & PAST & FLAT & LAST & LAMB \\
\hline & LAMP & DAMP & SLAP & STAMP & STAB \\
\hline & HANG & BANG & HAUNCH & RANG & HELD \\
\hline & FELT & MELT & FEAST & BELT & FIELD \\
\hline & BEEF & LEAF & BENT & REEF & BED \\
\hline & LEASE & PEACE & LEG & GEESE & SEA \\
\hline & LIFT & SHIFT & LIMP & SWIFT & LONG \\
\hline & HINGE & BINGE & HINT & FRINGE & HOUR \\
\hline & LIKE & STRIKE & LIES & SPIKE & LOVE \\
\hline & FIND & HIND & FISH & MIND & FIG \\
\hline & TIRE & WIRE & HIVE & SPIRE & TRIBE \\
\hline & BOLT & JOLT & BOAST & VOLT & ВоОТН \\
\hline & LOOSE & JUICE & LOUD & SPRUCE & LosS \\
\hline & NOUN & TOWN & CHOOSE & DOWN & NORM \\
\hline & HOPE & COPE & HORSE & MOPE & HALT \\
\hline & MUCK & LUCK & MUST & DUCK & MARSH \\
\hline & HUSH & LUSH & HUNT & MUSH & STUMP \\
\hline & FUDGE & JUDGE & SHUN & GRUDGE & HUGE \\
\hline \multirow[t]{14}{*}{$13-18$} & CAPE & DRAPE & CHARGE & SHAPE & DANCE \\
\hline & PACE & LACE & MATCH & RACE & MAZE \\
\hline & CAT & CHAT & CART & FLAT & MAN \\
\hline & PASS & BASS & PAD & MASS & PAIR \\
\hline & HASH & MASH & How & TRASH & HELM \\
\hline & PEACH & TEACH & SLEEP & REACH & PEAS \\
\hline & NECK & CHECK & FENCE & SPECK & NEED \\
\hline & BELL & SELL & FEEL & FELL & BEND \\
\hline & SCHEME & TEAM & STEM & SEAM & SKETCH \\
\hline & TILT & GUILT & TICKS & BUILT & TIN \\
\hline & PILL & WILL & PINCH & HILL & PURR \\
\hline & HIM & LIMB & HIT & SLIM & TAME \\
\hline & PINK & LINK & PINE & SINK & PIPE \\
\hline & HOWL & VOWEL & HAWK & TOWEL & HOLD \\
\hline
\end{tabular}


Appendix A (Continued)

\begin{tabular}{|c|c|c|c|c|c|c|}
\hline \multirow{2}{*}{$\begin{array}{c}\text { Prime } \\
\text { Set } \\
\text { Size } \\
\end{array}$} & & \multirow[b]{2}{*}{ Prime } & \multicolumn{2}{|c|}{ List 1} & \multicolumn{2}{|c|}{ List 2} \\
\hline & & & Related & Unrelated & Related & Unrelated \\
\hline \multirow{26}{*}{$19-30$} & LOCK & & ClOCK & LOFT & DOCK & LOT \\
\hline & LOOP & & HOOP & LAWN & SOUP & LOOT \\
\hline & HUNG & & STUNG & HURL & LUNG & HUB \\
\hline & BUG & & THUG & CUP & PLUG & BIRTH \\
\hline & HUNK & & SKUNK & HEARSE & BUNK & HUM \\
\hline & FILE & & PILE & FIRM & MILE & FERN \\
\hline & LAKE & & BAKE & PATH & RAKE & LACK \\
\hline & SANK & & SPANK & BARK & TANK & PANT \\
\hline & PAID & & FADE & FLAX & SPADE & SAND \\
\hline & PALE & & FAIL & PACT & PAIL & CRAFT \\
\hline & SEEN & & CLEAN & SLEPT & GREEN & SLEEVE \\
\hline & HEED & & FEED & HEM & SEED & HEAD \\
\hline & MESS & & GUESS & MERGE & LESS & MUSS \\
\hline & BEST & & NEST & BEAT & REST & FRET \\
\hline & BOWL & & POLE & COUGH & COAL & BOY \\
\hline & POUT & & SHOUT & POKE & scout & POOL \\
\hline & MOON & & TUNE & мотн & PRUNE & MOOD \\
\hline & HOSE & & ROSE & GONE & NOSE & HAUNT \\
\hline & MIGHT & & FIGHT & MILD & LIGHT & MIST \\
\hline & LIP & & SKIP & LICE & SHIP & LIME \\
\hline & SICK & & PICK & STIFF & SLICK & SAFE \\
\hline & PIN & & SKIN & PILE & THIN & PROM \\
\hline & HEAR & & FEAR & HELP & BEER & HOAX \\
\hline & PUFF & & STUFF & PERCH & BUFF & PURE \\
\hline & SING & & THING & SERVE & FLING & SELF \\
\hline & MEEK & & SEEK & DESK & REEK & HONK \\
\hline
\end{tabular}

Appendix B

Materials for Experiment 3

\begin{tabular}{|c|c|c|}
\hline $\begin{array}{l}\text { Prime Set } \\
\text { Size and } \\
\text { Strength }\end{array}$ & Prime & Target \\
\hline Small-Strong & $\begin{array}{l}\text { Mathematical Operation } \\
\text { Season of Year } \\
\text { Branch of Armed Services } \\
\text { Daily Meal } \\
\text { College Level } \\
\text { Venomous Snake } \\
\text { Writing Implement } \\
\text { Grammatical Part of Speech }\end{array}$ & $\begin{array}{l}\text { DIVISION } \\
\text { WINTER } \\
\text { NAVY } \\
\text { BREAKFAST } \\
\text { JUNIOR } \\
\text { COBRA } \\
\text { PENCIL } \\
\text { VERB }\end{array}$ \\
\hline Small-Weak & $\begin{array}{l}\text { Bird of Prey } \\
\text { Hair Color } \\
\text { Citrus Fruit } \\
\text { Eating Utensil } \\
\text { Part of Face } \\
\text { Insect that Stings } \\
\text { Primary Color } \\
\text { Precious Gem }\end{array}$ & $\begin{array}{l}\text { OWL } \\
\text { AUBURN } \\
\text { LIME } \\
\text { KNIFE } \\
\text { CHEEK } \\
\text { WASP } \\
\text { GREEN } \\
\text { SAPPHIRE }\end{array}$ \\
\hline Large-Strong & $\begin{array}{l}\text { Wild Animal } \\
\text { Type of Nut } \\
\text { Part of Boat } \\
\text { Cosmetic } \\
\text { Type of Relative }\end{array}$ & $\begin{array}{l}\text { BEAR } \\
\text { PECAN } \\
\text { BOW } \\
\text { BLUSH } \\
\text { UNCLE }\end{array}$ \\
\hline
\end{tabular}


Appendix B (Continued)

\begin{tabular}{|c|c|c|}
\hline $\begin{array}{l}\text { Prime Set } \\
\text { Size and } \\
\text { Strength }\end{array}$ & Prime & Target \\
\hline & $\begin{array}{l}\text { Water Bird } \\
\text { Type of Bread } \\
\text { Article of Clothing }\end{array}$ & $\begin{array}{l}\text { SEAGULL } \\
\text { RYE } \\
\text { PANTS }\end{array}$ \\
\hline Large-Weak & $\begin{array}{l}\text { Emotion } \\
\text { Kind of Liquor } \\
\text { Type of Building } \\
\text { Type of Flower } \\
\text { Felony Crime } \\
\text { Weapon } \\
\text { Type of Science } \\
\text { Natural Earth Formation }\end{array}$ & $\begin{array}{l}\text { PITY } \\
\text { BRANDY } \\
\text { APARTMENT } \\
\text { VIOLET } \\
\text { FRAUD } \\
\text { CANNON } \\
\text { GEOLOGY } \\
\text { CRATER }\end{array}$ \\
\hline Small-Strong & $\begin{array}{l}\text { Fairy } \\
\text { Rifle } \\
\text { Single } \\
\text { Vocal } \\
\text { Toast } \\
\text { Past } \\
\text { Bunch } \\
\text { Look }\end{array}$ & $\begin{array}{l}\text { HAIRY } \\
\text { STIFLE } \\
\text { SHINGLE } \\
\text { LOCAL } \\
\text { BOAST } \\
\text { FAST } \\
\text { LUNCH } \\
\text { BOOK }\end{array}$ \\
\hline Small-Weak & $\begin{array}{l}\text { Chief } \\
\text { Deliver } \\
\text { Actor } \\
\text { Swindle } \\
\text { Wage } \\
\text { Arrange } \\
\text { Blimp } \\
\text { Charm }\end{array}$ & $\begin{array}{l}\text { BEEF } \\
\text { LIVER } \\
\text { TRACTOR } \\
\text { KINDLE } \\
\text { PAGE } \\
\text { RANGE } \\
\text { LIMP } \\
\text { FARM }\end{array}$ \\
\hline Large-Strong & $\begin{array}{l}\text { Stick } \\
\text { Hay } \\
\text { Maid } \\
\text { Bake } \\
\text { Bee } \\
\text { Gum } \\
\text { Rose } \\
\text { Wine }\end{array}$ & $\begin{array}{l}\text { LICK } \\
\text { SAY } \\
\text { PAID } \\
\text { LAKE } \\
\text { SEE } \\
\text { HUM } \\
\text { HOSE } \\
\text { MINE }\end{array}$ \\
\hline Large-Weak & $\begin{array}{l}\text { Snack } \\
\text { Relax } \\
\text { Whale } \\
\text { Clam } \\
\text { Vain } \\
\text { Chair } \\
\text { Net } \\
\text { Disease }\end{array}$ & $\begin{array}{l}\text { PACK } \\
\text { TAX } \\
\text { PALE } \\
\text { HAM } \\
\text { PAIN } \\
\text { FAIR } \\
\text { BET } \\
\text { PLEASE }\end{array}$ \\
\hline
\end{tabular}

Appendix C

Materials Used in Experiment 4

\begin{tabular}{llllll}
\hline \multirow{2}{*}{$\begin{array}{c}\text { Prime Set } \\
\text { Size and } \\
\text { Strength }\end{array}$} & \multicolumn{2}{c}{ List 1} & \multicolumn{2}{c}{ List 2} \\
\cline { 2 - 3 } Small-Strong & Prime & \multicolumn{2}{c}{ Target } & Prime & Target \\
\cline { 2 - 3 } & \multicolumn{2}{c}{ Associatively Related Pairings } \\
& Dark & LIGHT & Bee & STING \\
& Cork & BOTTLE & Cat & MOUSE \\
& Cloud & SKY & Croak & DIE \\
& Fist & FIGHT & Razor & SHARP
\end{tabular}


Appendix C (Continued)

\begin{tabular}{|c|c|c|c|c|}
\hline \multirow{2}{*}{$\begin{array}{l}\text { Prime Set } \\
\text { Size and } \\
\text { Strength }\end{array}$} & \multicolumn{2}{|c|}{ List 1} & \multicolumn{2}{|c|}{ List 2} \\
\hline & Prime & Target & Prime & Target \\
\hline & $\begin{array}{l}\text { Frost } \\
\text { Gull } \\
\text { Fork } \\
\text { Hop } \\
\text { Galoshes } \\
\text { Grove } \\
\text { Inhale } \\
\text { Mongoose } \\
\text { Needle } \\
\text { Pail } \\
\text { Round } \\
\text { Thimble } \\
\text { Timber } \\
\text { Slim } \\
\text { Blade }\end{array}$ & $\begin{array}{l}\text { COLD } \\
\text { SEA } \\
\text { SPOON } \\
\text { JUMP } \\
\text { RAIN } \\
\text { ORANGES } \\
\text { EXHALE } \\
\text { ANIMAL } \\
\text { THREAD } \\
\text { BUCKET } \\
\text { SQUARE } \\
\text { SEW } \\
\text { WOOD } \\
\text { FAT } \\
\text { RAZOR }\end{array}$ & $\begin{array}{l}\text { Thirst } \\
\text { Dime } \\
\text { Gem } \\
\text { Dine } \\
\text { Dumb } \\
\text { Mule } \\
\text { Oven } \\
\text { Read } \\
\text { Saber } \\
\text { Search } \\
\text { Shine } \\
\text { Stem } \\
\text { Sweep } \\
\text { Train } \\
\text { Waves }\end{array}$ & $\begin{array}{l}\text { WATER } \\
\text { NICKLE } \\
\text { DIAMOND } \\
\text { EAT } \\
\text { STUPID } \\
\text { DONKEY } \\
\text { HEAT } \\
\text { WRITE } \\
\text { SWORD } \\
\text { LOOK } \\
\text { SUN } \\
\text { FLOWER } \\
\text { BROOM } \\
\text { TRACK } \\
\text { OCEAN }\end{array}$ \\
\hline Small-Weak & $\begin{array}{l}\text { Bee } \\
\text { Cat } \\
\text { Croak } \\
\text { Razor } \\
\text { Thirst } \\
\text { Dime } \\
\text { Gem } \\
\text { Dine } \\
\text { Dumb } \\
\text { Mule } \\
\text { Oven } \\
\text { Read } \\
\text { Saber } \\
\text { Search } \\
\text { Shine } \\
\text { Skull } \\
\text { Stem } \\
\text { Sweep } \\
\text { Train } \\
\text { Wave }\end{array}$ & $\begin{array}{l}\text { INSECT } \\
\text { KITTEN } \\
\text { DEATH } \\
\text { SHAVE } \\
\text { QUENCH } \\
\text { PENNY } \\
\text { RUBY } \\
\text { RESTAURANT } \\
\text { DEAF } \\
\text { STUBBORN } \\
\text { HEAT } \\
\text { LEARN } \\
\text { SAW } \\
\text { SEEK } \\
\text { GLOW } \\
\text { SKELETON } \\
\text { LEAF } \\
\text { MOP } \\
\text { STATION } \\
\text { SURF }\end{array}$ & $\begin{array}{l}\text { Dark } \\
\text { Cork } \\
\text { Cloud } \\
\text { Fist } \\
\text { Frost } \\
\text { Gull } \\
\text { Fork } \\
\text { Hop } \\
\text { Galoshes } \\
\text { Grove } \\
\text { Inhale } \\
\text { Mongoose } \\
\text { Needle } \\
\text { Pail } \\
\text { Round } \\
\text { Sight } \\
\text { Thimble } \\
\text { Timber } \\
\text { Slim } \\
\text { Blade }\end{array}$ & $\begin{array}{l}\text { BLACK } \\
\text { STOPPER } \\
\text { WHITE } \\
\text { PUNCH } \\
\text { ICE } \\
\text { BEACH } \\
\text { EAT } \\
\text { RABBIT } \\
\text { WET } \\
\text { COCONUT } \\
\text { SMOKE } \\
\text { COBRA } \\
\text { SHARP } \\
\text { SHOVEL } \\
\text { BALL } \\
\text { BLIND } \\
\text { THREAD } \\
\text { LUMBER } \\
\text { THIN } \\
\text { SHARP }\end{array}$ \\
\hline Large-Strong & $\begin{array}{l}\text { Amuse } \\
\text { Cause } \\
\text { Die } \\
\text { Flush } \\
\text { Food } \\
\text { Retain } \\
\text { Street } \\
\text { Speak } \\
\text { Dirt } \\
\text { Sit } \\
\text { Mash } \\
\text { Shoe } \\
\text { Tax } \\
\text { Blank } \\
\text { Crowd } \\
\text { Dorm } \\
\text { Harp } \\
\text { Prize } \\
\text { Boat } \\
\text { Church }\end{array}$ & $\begin{array}{l}\text { LAUGH } \\
\text { EFFECT } \\
\text { LIVE } \\
\text { TOILET } \\
\text { EAT } \\
\text { KEEP } \\
\text { ROAD } \\
\text { TALK } \\
\text { MUD } \\
\text { STAND } \\
\text { POTATO } \\
\text { FOOT } \\
\text { MONEY } \\
\text { EMPTY } \\
\text { PEOPLE } \\
\text { ROOM } \\
\text { MUSIC } \\
\text { WIN } \\
\text { WATER } \\
\text { GOD }\end{array}$ & $\begin{array}{l}\text { Neck } \\
\text { Gift } \\
\text { Wander } \\
\text { Bunch } \\
\text { Hill } \\
\text { Yarn } \\
\text { Sing } \\
\text { Charm } \\
\text { Hook } \\
\text { Wrench } \\
\text { Put } \\
\text { Offend } \\
\text { Sword } \\
\text { Book } \\
\text { Hand } \\
\text { Soft } \\
\text { Haze } \\
\text { Brain } \\
\text { Baby } \\
\text { Dish }\end{array}$ & $\begin{array}{l}\text { HEAD } \\
\text { PRESENT } \\
\text { LOST } \\
\text { GROUP } \\
\text { MOUNTAIN } \\
\text { KNIT } \\
\text { SONG } \\
\text { BRACELET } \\
\text { FISH } \\
\text { TOOL } \\
\text { PLACE } \\
\text { HURT } \\
\text { KNIFE } \\
\text { READ } \\
\text { FINGER } \\
\text { HARD } \\
\text { FOG } \\
\text { HEAD } \\
\text { CHILD } \\
\text { PLATE }\end{array}$ \\
\hline Large-Weak & $\begin{array}{l}\text { Neck } \\
\text { Gift } \\
\text { Wander }\end{array}$ & $\begin{array}{l}\text { THROAT } \\
\text { BIRTHDAY } \\
\text { ROAM }\end{array}$ & $\begin{array}{l}\text { Amuse } \\
\text { Cause } \\
\text { Die }\end{array}$ & $\begin{array}{l}\text { ENTERTAIN } \\
\text { REASON } \\
\text { CROAK }\end{array}$ \\
\hline
\end{tabular}


Appendix C (Continued)

\begin{tabular}{|c|c|c|c|c|}
\hline \multirow{2}{*}{$\begin{array}{c}\text { Prime Set } \\
\text { Size and } \\
\text { Strength }\end{array}$} & \multicolumn{2}{|c|}{ List 1} & \multicolumn{2}{|c|}{ List 2} \\
\hline & Prime & Target & Prime & Target \\
\hline & Bunch & FLOWERS & Flush & BLUSH \\
\hline & Hill & SLOPE & Food & DRINK \\
\hline & Yarn & WOOL & Retain & REMEMBER \\
\hline & Sing & DANCE & Street & CAR \\
\hline & Charm & WIT & Speak & LISTEN \\
\hline & Hook & SINKER & Dirt & SOIL \\
\hline & Wrench & HAMMER & Sit & RELAX \\
\hline & Put & TAKE & Mush & SQUASH \\
\hline & Offend & INSULT & Shoe & HORN \\
\hline & Sword & SHARP & $\operatorname{Tax}$ & INCOME \\
\hline & Book & SCHOOL & Blank & NOTHING \\
\hline & Hand & ARM & Crowd & MOB \\
\hline & Soft & CUDDLE & Dorm & HOUSE \\
\hline & Haze & MIST & Harp & STRING \\
\hline & Brain & SMART & Prize & MONEY \\
\hline & Baby & SMALL & Boat & SHIP \\
\hline & Dish & CUP & Church & RELIGION \\
\hline \multicolumn{5}{|c|}{ Rhyme-Related Pairings } \\
\hline Small-Strong & Bolt & $\operatorname{coLT}$ & Boast & HOST \\
\hline & Knife & LIFE & Fiddle & RIDDLE \\
\hline & Milk & SILK & Hunch & LUNCH \\
\hline & Lisp & WISP & Chisel & FIZZLE \\
\hline & Paddle & SADDLE & Hem & STEM \\
\hline & Tusk & MUSK & Varnish & TARNISH \\
\hline & Pounce & BOUNCE & Annual & MANUAL \\
\hline & Cloth & SLOTH & Liver & SHIVER \\
\hline & Hard & LARD & Lurch & PERCH \\
\hline & Dish & WISH & Lazy & HAZY \\
\hline & House & MOUSE & Ridge & BRIDGE \\
\hline & Fashion & PASSION & Blast & CAST \\
\hline & Roach & COACH & Loose & MOOSE \\
\hline & Halt & SALT & Risk & DISK \\
\hline & Barge & LARGE & Hound & POUND \\
\hline & Goof & ROOF & Love & DOVE \\
\hline & Alarm & ARM & First & BURST \\
\hline & Egg & BEG & Cup & PUP \\
\hline & Factor & TRACTOR & Beef & LEAF \\
\hline & Handle & CANDLE & Bench & WRENCH \\
\hline \multirow[t]{20}{*}{ Small-Weak } & Boast & POST & Bolt & VOLT \\
\hline & Fiddle & PIDDLE & Knife & WIFE \\
\hline & Hunch & BRUNCH & Milk & BILK \\
\hline & Chisel & DRIZZLE & Lisp & CRISP \\
\hline & Hem & THEM & Paddle & STRADDLE \\
\hline & Varnish & GARNISH & Tusk & HUSK \\
\hline & Annual & GRANNUAL & Pounce & TROUNCE \\
\hline & Liver & SLIVER & Cloth & BROTH \\
\hline & Lurch & SEARCH & Hard & YARD \\
\hline & Lazy & DAISY & Dish & SWISH \\
\hline & Ridge & MIDGE & House & BLOUSE \\
\hline & Blast & MAST & Fashion & RATION \\
\hline & Loose & MOOSE & Roach & BROACH \\
\hline & Risk & BRISK & Halt & VAULT \\
\hline & Hound & BOUND & Barge & SARGE \\
\hline & Love & GLOVE & Goof & SPOOF \\
\hline & First & THIRST & Alarm & ARM \\
\hline & Cup & sup & Egg & KEG \\
\hline & Beef & GRIEF & Factor & REACTOR \\
\hline & Bench & QUENCH & Handle & SANDAL \\
\hline
\end{tabular}


Appendix C (Continued)

\begin{tabular}{|c|c|c|c|c|}
\hline \multirow{2}{*}{$\begin{array}{l}\text { Prime Set } \\
\text { Size and } \\
\text { Strength }\end{array}$} & \multicolumn{2}{|c|}{ List 1} & \multicolumn{2}{|c|}{ List 2} \\
\hline & Prime & Target & Prime & Target \\
\hline \multirow[t]{20}{*}{ Large-Strong } & Chair & HAIR & Cave & SAVE \\
\hline & Fail & JAIL & Lake & BAKE \\
\hline & Cone & BONE & Feet & BEAT \\
\hline & Drum & RUM & Soar & ROAR \\
\hline & Balloon & SALOON & Row & Bow \\
\hline & Hide & RIDE & Tick & LICK \\
\hline & Saw & LAW & Nest & BEST \\
\hline & Cheek & MEEK & Chop & HOP \\
\hline & String & RING & Pill & HILL \\
\hline & Clock & LOCK & Mice & RICE \\
\hline & Cane & LANE & Flame & BLAME \\
\hline & Tip & LIP & Late & MATE \\
\hline & See & $\mathrm{BEE}$ & Lie & TIE \\
\hline & Pain & RAIN & Pole & HOLE \\
\hline & Ham & SAM & Pink & STINK \\
\hline & Brat & CAT & Dress & MESS \\
\hline & Rank & BANK & Bend & LEND \\
\hline & Nation & STATION & Bell & HELL \\
\hline & Load & MODE & Dash & TRASH \\
\hline & Queen & MEAN & Fist & LIST \\
\hline \multirow[t]{20}{*}{ Large-Weak } & Cave & PAVE & Chair & AIR \\
\hline & Lake & SAKE & Fail & MAIL \\
\hline & Feet & MEET & Cone & TONE \\
\hline & Soar & OAR & Drum & COME \\
\hline & Row & Tow & Balloon & RACCOON \\
\hline & Tick & wick & Hide & WIDE \\
\hline & Nest & TEST & Saw & CLAW \\
\hline & Chop & SHOP & Cheek & BEAK \\
\hline & Pill & SILL & String & FLING \\
\hline & Mice & DICE & Clock & MOCK \\
\hline & Flame & SHAME & Cane & STAIN \\
\hline & Late & RATE & Tip & ZIP \\
\hline & Lie & BUY & See & TREE \\
\hline & Pole & DOLE & Pain & MAIN \\
\hline & Pink & WINK & Ham & SLAM \\
\hline & Dress & STRESS & Brat & FLAT \\
\hline & Bend & BLEND & Rank & BLANK \\
\hline & Bell & WELL & Nation & INFLATION \\
\hline & Dash & FLASH & Load & MOWED \\
\hline & Fist & GIST & Queen & DEAN \\
\hline
\end{tabular}

(Manuscript received August 27, 1989;

revision accepted for publication June 4, 1990.) 